\title{
Effect of Zinc Supplementation on Respiratory Tract Infections in Children With Cystic Fibrosis
}

\author{
I. Abdulhamid, $\mathrm{MD}^{1 *}{ }^{1 *}$ F.W.J. Beck, $\mathrm{PhD},{ }^{2}$ S. Millard, $\mathrm{MD},{ }^{3}$ X. Chen, $\mathrm{MD}, \mathrm{PhD},{ }^{1}$ and A. Prasad, $\mathrm{MD}, \mathrm{PhD}^{2}$
}

\begin{abstract}
Summary. Zinc (Zn) has significant anti-oxidant and anti-inflammatory activity. Zn deficiency can occur in subsets of patients with cystic fibrosis (CF) especially those with malabsorption and impaired growth. Although supplemental $\mathrm{Zn}$ has significantly reduced infections in various disorders, its efficacy has not been thoroughly investigated in CF. We performed a double blind placebo controlled pilot study to investigate the effect of daily $30 \mathrm{mg}$ elemental $\mathrm{Zn}$ for 1 year on the rate of respiratory tract infections (RTIs), use of antibiotics and plasma cytokines in 26 children with CF (ages 7-18 years). Plasma Zn, Cu, inflammatory cytokines and ex vivo generation of IL-2 were measured at baseline and at the end of the study. The number of days of oral antibiotics was lower in $\mathrm{Zn}$ treated patients compared to placebo $(P=0.05)$. However, compared to placebo, the effect of $\mathrm{Zn}$ was greater in patients who exhibited low plasma $\mathrm{Zn}$ at baseline $(P=0.02)$ than those who had plasma $\mathrm{Zn}$ levels identical to normal subjects $(P=0.55)$. $\mathrm{Zn}$ supplementation was marginally effective in reducing percentage increase in plasma IL- 6 and IL-8 while increasing the percentage change in ex vivo generation of IL-2 in isolated mononuclear cell. In conclusion, oral intake of $30 \mathrm{mg} /$ day of $Z \mathrm{n}$ reduced the number of days of oral antibiotics used to treat RTIs in children with CF. A higher daily $\mathrm{Zn}$ dose may be needed to decrease RTIs and modify immune responses. Pediatr Pulmonol. 2008; 43:281-287. ๑ 2008 Wiley-Liss, Inc.
\end{abstract}

Key words: cystic fibrosis; respiratory tract infections; zinc; cytokines.

\section{INTRODUCTION}

Cystic fibrosis (CF) is an autosomal recessive disease caused by genetic mutations that code for cyclic AMPactivated chloride channel, the CF transmembrane regulator (CFTR). ${ }^{1-3}$ The disease affects many organ systems, particularly the respiratory and gastrointestinal tracts. Due to pancreatic insufficiency, malabsorption of essential fatty acids, fat-soluble vitamins, and various trace elements, including zinc ( $\mathrm{Zn})$, can occur in subjects with $\mathrm{CF}^{4,5}$ The airways in patients with $\mathrm{CF}$ are uniquely susceptible to chronic infections with various bacterial agents, especially Gram negative organisms such as pseudomonas aeroginosa. ${ }^{6}$ This infection causes the release of inflammatory cytokines, proteolytic enzymes, and oxygen radicals which leads to bronchiectasis, increased dead space, hypoxia, and hypercapnea. ${ }^{7,8}$

Approximately $90 \%$ of patients die of respiratory failure as a result of chronic bacterial infections, Treatment of CF lung disease is aimed at reducing airway obstruction, treating recurrent infections, improving airway clearance, and maintaining optimal nutritional status. $^{9-11}$

$\mathrm{Zn}$ is an integral part of the structure and function of many biological enzymes and a regulator of ion transporters relevant to pulmonary function and disease in $\mathrm{CF}$ and other pulmonary disorders. ${ }^{11-13} \mathrm{Zn}$ is also known to exhibit powerful anti-oxidant activity in several organ systems including the lungs. ${ }^{11,13}$ For example, $\mathrm{Zn}$ deficient rats developed significant lung toxicity 1 day after exposure to high oxygen concentrations and $\mathrm{Zn}$ replenishment prevented the hyperoxia lung damage in previously $\mathrm{Zn}$ deficient animals. ${ }^{14}$

$\mathrm{Zn}$ supplementation to non-CF infants and pre-school children resulted in reduced incidence of acute lower respiratory infections. ${ }^{15} \mathrm{Zn}$ supplementation lead to the reduction of plasma concentration of inflammatory cytokines, and oxidative stress markers in the absence of

${ }^{1}$ Pediatric Pulmonary Division, The Carman and Ann Adams Department of Pediatrics, Children's Hospital of Michigan (CHM), Wayne State University (WSU), Detroit, Michigan.

${ }^{2}$ Department of Internal Medicine, WSU, Detroit, Michigan.

${ }^{3}$ Pediatric Pulmonary Division, DeVos Children's Hospital, Grand Rapids, Michigan.

Grant sponsor: Children's Research Center of Michigan at CHM.

*Correspondence to: I. Abdulhamid, MD, Pediatric Pulmonary Division, Children's Hospital of Michigan, 3901 Beaubien Blvd, Detroit, MI 48201. E-mail: ihamid@med.wayne,edu

Received 29 May 2007; Revised 10 November 2007; Accepted 13 November 2007.

DOI 10.1002/ppul.20771

Published online in Wiley InterScience

(www.interscience.wiley.com). 
infection, ${ }^{16}$ and decreased the duration of colds in healthy young adults. ${ }^{17}$ It also lowered the incidence of infection and inflammatory cytokines levels in healthy elderly subjects. ${ }^{18}$

Using plasma and red cell $\mathrm{Zn}$ concentrations to reflect $\mathrm{Zn}$ status in CF has produced conflicting results as not all $\mathrm{CF}$ patients appear to exhibit low Zn status. ${ }^{19}$ Administration of supplemental $\mathrm{Zn}$ to $\mathrm{CF}$ patients has also been non-conclusive for in one study, $\mathrm{Zn}$ therapy did not result in improvement of clinical status, growth velocity or pulmonary function. ${ }^{20}$ Another study showed an association between low $\mathrm{Zn}$ status and impaired IL-2 activity, NK activity and thymulin activity in CF subjects, but there was no investigation as whether these parameters would be corrected following $\mathrm{Zn}$ supplementation. ${ }^{21}$

With these premises we initiated a pilot study to determine whether $\mathrm{Zn}$ supplementation administered to CF patients during a year long double blinded placebo controlled trial would reduce the requirement for oral antibiotics necessary during periods of active infection. We also assessed whether changes in selected plasma inflammatory cytokines and the ex vivo generation of IL-2 would be altered by oral $\mathrm{Zn}$ therapy. And lastly, we investigated the hypothesis that a response to $\mathrm{Zn}$ supplementation would be different in subjects with low plasma $\mathrm{Zn}$ levels compared to those expressing normal plasma $\mathrm{Zn}$ levels.

\section{MATERIALS AND METHODS}

\section{Subjects and Controls}

For this double blind placebo controlled study, a total of 26 children with $\mathrm{CF}$ exhibiting mild to moderate lung disease groups A and B were recruited from the Pediatric Pulmonary Division, Carman and Ann Adams Department of Pediatrics, Children's Hospital of Michigan (CHM), and the Pediatric Pulmonary Division, DeVos Children's Hospital, Grand Rapids, Michigan. Subject's ages ranged from 7 to 18 years old. Exclusion criteria for the study included presence of acute severe infection at the time of enrollment, renal disease, severe hepatic disease, gall bladder disease, sickle cell disease (SCD), use of oral immunosuppressive drugs (steroids and nonsteroid anti-inflammatory drugs), diuretics and Zn supplements. The study was approved by the Human Investigative Committees in both institutions. Informed and signed consent was obtained from parents or legal guardians.

\section{Study Groups}

Without respect to prior $\mathrm{Zn}$ status, CF subjects were randomly assigned to Group A $(n=13)$ received a daily dose of $30 \mathrm{mg}$ of elemental $\mathrm{Zn}$ as $\mathrm{Zn}$ gluconate (15 mg/capsule) and CF subjects assigned to Group B $(n=13)$ received placebo for 12 consecutive months. $\mathrm{Zn}$ gluconate and placebo preparations were capsules generously provided by Labcatal, Montrouge, France for use in this study. Both groups were given identical daily $\mathrm{Zn}$-free and mineral-free multivitamin supplements for the same period (Vitamax ${ }^{\circledR}$ from SK Labs, Chesterfield, MO) supplied by the CF services Pharmacy. Patients in groups A and B were followed every 3 months and as needed in their $\mathrm{CF}$ clinics for routine $\mathrm{CF}$ care. At each visit, the patient's interval medical history, height and weight, number of hospitalizations, the use of oral and intravenous antibiotics, pulmonary function test, and physical examination findings were recorded.

Respiratory tract infections (RTIs) was defined when the patient developed more than four of the following signs or symptoms: change in sputum; new or increased hemoptysis; increased cough; increased dyspnea; malaise, fatigue, or lethargy; temperature above $38^{\circ} \mathrm{C}$; anorexia or weight loss; sinus pain or tenderness; change in nasal or sinus discharge; change in physical examination of the chest; decrease in pulmonary function from a previously recorded value; or radiographic changes indicative of pulmonary infection.

Choice and duration of oral or parenteral antibiotics used for treatment of RTIs were left to the discretion of the children's treating physicians.

Ten milliliter of heparinized whole blood was collected at baseline and at the end of the study for determination of plasma $\mathrm{Zn}, \mathrm{Cu}$ and the inflammatory cytokines, TNF- $\alpha$ IL-1 $\beta$ IL-6 IL-8, soluble IL-1 receptor antagonist (sIL-1RA) and soluble TNF- $\alpha$ receptor 1 (sTNFR1). Peripheral blood mononuclear cells (PBMC) were isolated for ex vivo generation of IL-2. ${ }^{18,22}$ Sterile procedures were carried out on all samples to ensure no contaminants would interfere with the ELISA assays or ex vivo generation of IL-2. Plasma samples were centrifuged at $1,500 \mathrm{~g}$ for $20 \mathrm{~min}$ at room temperature to remove cellular components before being stored in $1 \mathrm{ml}$ aliquots at $-20^{\circ} \mathrm{C}$ for ELISA assays or being admixed with trace metal free Ultrex II Nitric Acid (J.T. Baker Chemicals, Phillipsburg, NJ) and digested for $\mathrm{Zn}$ and copper analysis by flameless atomic absorption (AA). ${ }^{18,22}$

\section{Laboratory Measurements}

Aliquots of plasma samples were stored at $-20^{\circ} \mathrm{C}$ until assayed for cytokines to ensure that both pre- and postsamples could be determined using the same highsensitivity ELISA kits available from R\&D Systems (Minneapolis, MN). Plasma $\mathrm{Zn}$ and $\mathrm{Cu}$ levels were determined by flameless AA spectrophotometry with a Zeeman background corrector (AA220Z Varian, Sugarland, TX). ${ }^{18,22}$

PBMCs were isolated by discontinuous density gradient using Histopaque 1077 (Sigma-Aldrich, St. Louis, MO) 
according to the manufacturer's protocol. Isolated PMNC were resuspended in incubation media consisting of RPMI1640 supplemented with $10 \%$ fetal bovine serum, $1.5 \mathrm{gm} / \mathrm{L}$ sodium bicarbonate, $0.1 \%$ gentamicin, $2 \mathrm{mM}$ L-glutamine and $50 \mu \mathrm{M} \beta$-mercaptoethanol. Cells were stimulated for $48 \mathrm{hr}$ with $10 \mu \mathrm{g} / \mathrm{ml}$ PHA-p (Sigma, St. Louis, MO) at $37^{\circ} \mathrm{C}$ under an atmosphere of $85 \%$ air $/ 5 \% \mathrm{CO}_{2}$. At the termination of the experiment, supernatants were harvested and assayed for IL-2 by ELISA (Quantikine ELISA, R\&D Systems).

\section{Characterization of $\mathbf{Z n}-$ Versus $\mathbf{Z n}+$ Subjects}

$\mathrm{Zn}$ adequate $\mathrm{CF}$ subjects $(\mathrm{Zn}+)$ were defined as those subjects with $\geq 90 \mu \mathrm{g} / \mathrm{dl}$ plasma $\mathrm{Zn}$ as determined by flameless AA at baseline. Subjects exhibiting inadequate $\mathrm{Zn}$ status $(\mathrm{Zn}-$ ) had plasma $\mathrm{Zn}$ levels $\leq 89 \mu \mathrm{g} / \mathrm{dl}$ or two standard deviations below our normal database of $110 \pm 10 \mu \mathrm{g} \mathrm{Zn} / \mathrm{dl}^{18,22}$ Although all subjects exhibited plasma $\mathrm{Zn}$ levels within the clinically accepted "normal" range $(70-120 \mu \mathrm{g} / \mathrm{dl}),{ }^{23}$ results from a number of our research studies have demonstrated that subjects exhibiting low Zn levels $(<90 \mu \mathrm{g} / \mathrm{dl})$ are more susceptible to infections and tend to have higher levels of plasma oxidative stress molecules and inflammatory cytokines even in the absence of outward infections. ${ }^{18,22}$

\section{Statistical Analyses}

Baseline data comparison between $\mathrm{Zn}$ adequate and $\mathrm{Zn}$ inadequate CF patients were determined by the Student's $t$-test. Data representing differences between pre- and post-values were analyzed using the Student's $t$-test for plasma cytokines $\mathrm{Zn}$ and $\mathrm{Cu}$ and ex vivo generation of IL-2, as well as for weight, height, hemoglobin, and FEV ${ }_{1}$. Correlation between compliance and days of oral antibiotic usage was determined by regression analysis using Pearson r (GraphPad Instat Ver. 3.05 for Windows95/NT, San Diego, CA).

\section{RESULTS}

Overall, there were no statistical differences in the baseline parameters examined between $\mathrm{Zn}$ adequate and inadequate $\mathrm{CF}$ children with the exception of plasma $\mathrm{Zn}$ status (Table 1). Zn adequate CF patients also tended to have higher levels of the sIL-1RA, IL- $1 \beta$, and IL- 6 and although the differences did not reach statistical significance (Table 1).

$\mathrm{Zn}$ supplementation administered to $12 \mathrm{CF}$ patients (one subject dropped) resulted in a significant $(P=0.05)$ reduction in the number of days of oral antibiotics use per year compared to the 13 patients on placebo. However, the response to $\mathrm{Zn}$ supplementation was different for the $\mathrm{Zn}$ inadequate versus $\mathrm{Zn}$ adequate $\mathrm{CF}$ patients. Average days of antibiotic use for the $\mathrm{Zn}$ adequate $\mathrm{CF}$ subjects given $\mathrm{Zn}$ were not different from those given the placebo $(P=0.55$; Table 2$)$. This is in contrast to the response from the $\mathrm{Zn}$ inadequate $\mathrm{CF}$ subjects in which the effect of $\mathrm{Zn}$ supplementation was significantly greater $(P=0.025)$ compared to those given placebo (Table 2$)$.

Compliance of $\mathrm{Zn}$ adequate $\mathrm{CF}$ subjects given $\mathrm{Zn}$ was less than placebo treated $\mathrm{Zn}$ adequate subjects (Table 2).

TABLE 1-Baseline Characteristics of Subject Population

\begin{tabular}{|c|c|c|c|}
\hline Parameter & $\begin{array}{l}\text { Zinc adequate subjects } \\
\qquad(\mathrm{n}=13)\end{array}$ & $\begin{array}{l}\text { Zinc inadequate subjects } \\
\qquad(\mathrm{n}=13)\end{array}$ & $P$-value \\
\hline Age (year) & $12.0 \pm 3.4(7-17)^{1}$ & $11.8 \pm 3.6(8-18)$ & 0.8854 \\
\hline Weight (kg) & $37.58 \pm 13.6(23-67)$ & $42.67 \pm 13.0(21-59.7)$ & 0.3391 \\
\hline Height $(\mathrm{cm})$ & $146.53 \pm 17.12(124-178)$ & $147.87 \pm 14.44(123-167)$ & 0.8310 \\
\hline $\operatorname{Hbg}(\mathrm{g} / \mathrm{dl})$ & $13.66 \pm 0.85(12.2-15.2)$ & $13.66 \pm 0.68(12.5-15.0)$ & 0.9999 \\
\hline $\mathrm{Pl}^{2} \mathrm{Zn}(\mu \mathrm{g} / \mathrm{dl})$ & $101 \pm 9.8(90-125)$ & $82 \pm 4.9(73-89)$ & $<0.0001$ \\
\hline $\mathrm{Pl} . \mathrm{Cu}(\mu \mathrm{g} / \mathrm{dl})$ & $106 \pm 20(80-150)$ & $113 \pm 20(66-142)$ & 0.3811 \\
\hline FVC-P $\mathrm{P}^{3}$ & $83.85 \pm 12.1(65-98)$ & $87.0 \pm 10.8(70-104)$ & 0.4908 \\
\hline $\mathrm{FEV}_{1} \mathrm{P}^{4}$ & $67.5 \pm 17.7(41-100)$ & $76.77 \pm 15.3(54-98)$ & 0.1660 \\
\hline $\mathrm{FEF}_{25-75} \mathrm{P}^{5}$ & $48.69 \pm 29.47(10-109)$ & $65.38 \pm 32.43(12-109)$ & 0.1829 \\
\hline Gen. IL- $2^{6}$ & $411 \pm 529(25-1590)$ & $382 \pm 695(3-2370)$ & 0.9058 \\
\hline Pl. sIL-1ra (pg/ml) & $1501 \pm 1880(149-6900)$ & $927 \pm 938(131-2995)$ & 0.3384 \\
\hline Pl. sTNF-R1 (pg/ml) & $1368 \pm 887(348-3017)$ & $1179 \pm 463(716-2060)$ & 0.5054 \\
\hline Pl. IL-1 $\beta(\mathrm{pg} / \mathrm{ml})$ & $2.48 \pm 2.66(0.35-7.1)$ & $1.47 \pm 1.08(0.43-3.6)$ & 0.2240 \\
\hline Pl. TNF- $\alpha(\mathrm{pg} / \mathrm{ml})$ & $2.84 \pm 2.13(1.5-9.3)$ & $2.30 \pm 1.05(1.15-4.6)$ & 0.4236 \\
\hline Pl. IL-6 (pg/ml) & $6.18 \pm 5.71(1.8-18.6)$ & $3.82 \pm 4.99(0.52-17.2)$ & 0.2734 \\
\hline Pl. IL-8 (pg/ml) & $440 \pm 864(0-2858)$ & $581 \pm 1427(0-5552)$ & 0.7639 \\
\hline
\end{tabular}

\footnotetext{
${ }^{1}$ Values represent Mean $\pm \mathrm{SD}$ (range).

${ }^{2} \mathrm{Pl}$. represents plasma values.

${ }^{3} \mathrm{FVC}-\mathrm{P}=$ forced vital capacity expressed as percent predicted.

${ }^{4} \mathrm{FEV}_{1} \mathrm{P}=$ forced expiratory volume in $1 \mathrm{sec}$, expressed as a percentage of predicted.

${ }^{5} \mathrm{FEF}_{25-75} \mathrm{P}=$ forced expiratory flow between 75 and 25 of $\mathrm{FVC}$ expressed as percent predicted.

${ }^{6} \mathrm{IL}-2$ generated ex vivo.
} 
TABLE 2-Number of Episodes Requiring Antibiotics, Number of Days of Oral Antibiotic Usage and Compliance in Zinc and Placebo Supplemented Subjects With Cystic Fibrosis

\begin{tabular}{|c|c|c|c|c|c|c|}
\hline \multirow[b]{2}{*}{ Parameter } & \multicolumn{3}{|c|}{ Zinc adequate subjects } & \multicolumn{3}{|c|}{ Zinc inadequate subjects } \\
\hline & Placebo $(n=7)$ & Zinc $(n=5)$ & $P$-value & Placebo $(n=6)$ & $\operatorname{Zinc}(\mathrm{n}=7)$ & $P$-value \\
\hline No. of episodes req. i.v. $\mathrm{AB}^{1}$ & $0.57 \pm 0.53^{2}$ & $0.40 \pm 0.55$ & 0.559 & $0.17 \pm 0.41$ & $0.14 \pm 0.37$ & 0.915 \\
\hline No. of episodes req. oral $\mathrm{AB}^{3}$ & $3.28 \pm 2.9$ & $2.6 \pm 0.89$ & 0.574 & $3.16 \pm 1.6$ & $1.57 \pm 0.97$ & 0.049 \\
\hline$\%$ Compliance $^{4}$ & $92.8 \pm 7.6$ & $66.7 \pm 21.1$ & 0.012 & $81.4 \pm 18.8$ & $70.3 \pm 37.7$ & 0.566 \\
\hline Avg. days/year Req. oral $\mathrm{AB}^{5}$ & $49.1 \pm 36.6$ & $37.4 \pm 6.0$ & 0.55 & $47.5 \pm 24.3$ & $20.5 \pm 12.8$ & 0.025 \\
\hline
\end{tabular}

${ }^{1}$ Average number of episodes/year requiring intravenous (i.v.) antibiotics.

${ }^{2}$ Values represent Mean \pm S.D.

${ }^{3}$ Average number of episodes/year requiring oral antibiotics.

${ }^{4}$ Average percent compliance.

${ }^{5}$ Average days/year requiring oral antibiotic use.

However, overall compliance of the two groups of $\mathrm{Zn}$ treated subjects was similar. Moreover, Pearson correlation coefficient indicated no correlation between compliance and number of days of oral antibiotic usage in all $\mathrm{Zn}$ supplemented subjects $\left(\mathrm{r}^{2}=0.025\right)$. There were no adverse events identified for any of the subjects in this study from oral or i.v. antibiotic use, $\mathrm{Zn}$ or placebo supplementation or any other parameter associated with this study.

Analysis of pre- versus post-values for each parameter resulted in non-significant percent change compared to baseline in selected parameters between the Zn supplemented and placebo supplemented group (Table 3). This was more likely due to the small number of patients and the large standard deviation within each group consisting of both $\mathrm{Zn}$ inadequate and and $\mathrm{Zn}$ adequate $\mathrm{CF}$ patients. In Zn treated CF patients, Zn supplementation was associated with less increase in plasma IL6 and IL-8, and a greater increase in plasma sIL-1ra and the ex vivo generation of IL-2 (Table 3). This may indicate an antiinflammatory role of $\mathrm{Zn}$ in this group of patients.

TABLE 3-Percentage Increase (Decrease) in Selected Parameters Obtained From Zinc and Placebo Supplemented Cystic Fibrosis Subjects

\begin{tabular}{lccc}
\hline Parameter & $\begin{array}{c}\text { Placebo Tx } \\
(\mathrm{n}=13)\end{array}$ & $\begin{array}{c}\text { Zinc Tx } \\
(\mathrm{n}=12)\end{array}$ & $P$-value \\
\hline $\mathrm{Pl}^{2}$. Zn $(\mu \mathrm{g} / \mathrm{dl})$ & $8.6 \pm 22^{3}$ & $6.1 \pm 9.4$ & 0.73 \\
Pl. sIL-1ra $(\mathrm{pg} / \mathrm{ml})$ & $1.9 \pm 141$ & $11.4 \pm 101$ & 0.84 \\
Pl. sTNFR1 $(\mathrm{pg} / \mathrm{ml})$ & $9.7 \pm 56$ & $8.1 \pm 27$ & 0.93 \\
Pl. IL-1 $\beta(\mathrm{pg} / \mathrm{ml})$ & $86 \pm 304$ & $78 \pm 188$ & 0.94 \\
Pl. TNF- $\alpha(\mathrm{pg} / \mathrm{ml})$ & $26 \pm 93$ & $32 \pm 87$ & 0.85 \\
Pl. IL-6 $(\mathrm{pg} / \mathrm{ml})$ & $173 \pm 374$ & $106 \pm 192$ & 0.57 \\
Pl. IL-8 $(\mathrm{pg} / \mathrm{ml})$ & $481 \pm 1507$ & $122 \pm 337$ & 0.41 \\
Gen ${ }^{4}$. IL-2 $(\mathrm{pg} / \mathrm{ml})$ & $55 \pm 274$ & $185 \pm 275$ & 0.24 \\
\hline
\end{tabular}

${ }^{1} P$ values for difference between placebo and zinc supplemented group. ${ }^{2} \mathrm{Pl}$. represents plasma.

${ }^{3}$ Mean \pm SD percent change from baseline.

${ }^{4}$ Ex vivo generation of IL-2 in PHA-p stimulated mononuclear cells.

\section{DISCUSSION}

A number of investigators have reported conflicting relationships between $\mathrm{Zn}$ status and malabsorption, impaired growth, or pulmonary function in $\mathrm{CF}$ patients. ${ }^{5,19,21,24,25-28}$ Few studies found no correlation between $\mathrm{Zn}$ levels and nutritional or pulmonary status ${ }^{19,25}$ Other reports found abnormal $\mathrm{Zn}$ status in certain patients with CF especially those with moderate to severe growth retardation and severe pulmonary disease. ${ }^{26-28}$ Low plasma $\mathrm{Zn}$ in $\mathrm{CF}$ was also associated with low plasma IL-2 levels, and an impairment of NK cell activity and low thymulin activity. ${ }^{21}$ Thymulin activity, necessary for the development of IL-2 producing $\mathrm{T}$ lymphocytes, was dependent upon the presence of the $\mathrm{Zn}$ molecule being present in the thymulin peptide structure. ${ }^{29}$ An increase in the number of CD3+ lymphocytes positive for IL-2 after stimulation has been reported in CF but was not correlated with Zn status. ${ }^{30}$ In this present study, isolated PMNC from $\mathrm{Zn}$ supplemented CF patients had increased ability of generating IL-2 over the time compared to those from subjects administered placebo.

While some studies showed an association between $\mathrm{Zn}$ deficiency, growth retardation and malnutrition in a subset of patients with $\mathrm{CF}$, our group of CF subjects did not appear to be "Zn deficient" but had plasma Zn levels still within clinically acceptable normal range. ${ }^{23}$ Based on our long term studies in trace metal research, we have found that subjects with plasma levels of $<90 \mu \mathrm{g} / \mathrm{dl}$ are more likely to suffer adverse reactions to immunological challenges such as cold, flu and infections than those subjects with plasma $\mathrm{Zn}$ levels above this range. In this study, $\mathrm{Zn}$ inadequate $\mathrm{CF}$ subjects exhibited lower baseline levels of plasma sIL-1ra, sTNFR1, IL-1 $\beta$, IL-6, and IL-8 than their $\mathrm{Zn}$ adequate counterpart. One hypothesis may be that in $\mathrm{CF}$ subjects with low plasma Zn levels, maintainence of immunological surveillance is decreased in the absence of acute exacerbation. In CF subjects with inadequate $\mathrm{Zn}$ status, $\mathrm{Zn}$ therapy was associated with 
significantly fewer days of oral antibiotics and insignificant change in plasma inflammatory cytokines pre- to post-therapy than their $\mathrm{Zn}$ adequate counterpart. However, the small number of subjects and large SD for selected parameters are not optimal for determination of a greater beneficial effect for $\mathrm{Zn}$ inadequate subjects compared to their $\mathrm{Zn}$ adequate counterpart. Changes in plasma $\mathrm{Zn}$ levels, weight, height, FEV1, and $\mathrm{Hgb}$ in $\mathrm{CF}$ receiving $\mathrm{Zn}$ were not different from the placebo treated CF group. This suggests that the dose of $\mathrm{Zn}(30 \mathrm{mg} /$ day) may not have been sufficient to affect growth rate or other parameters of lung function due to possible suboptimal absorption of $\mathrm{Zn}$ from the gastrointestinal tract. Slightly higher dose of $\mathrm{Zn}$ (no greater than $45 \mathrm{mg}$ ) may produce a more favorable response on anthropometric, and lung function measures. In patients with SCD in which loss of $\mathrm{Zn}$ due to red cell destruction and hyperzincuria leaves approximately $70 \%$ of SCD subject with mild to moderate $\mathrm{Zn}$ deficiency, supplemental $\mathrm{Zn}$ in dosages of $50-75 \mathrm{mg} /$ day are required to reduce incidence of infection and the presence of endogenous plasma inflammatory cytokines. ${ }^{31}$ Supplemental $\mathrm{Zn}$ at $45 \mathrm{mg} / \mathrm{day}$ has been shown to reduce the incidence of infection and reduce plasma inflammatory cytokines in the elderly population even in the absence of active infection ${ }^{18}$ and to reduce the presence of oxidative stress markers in young adults without adverse effects or changes in copper levels. ${ }^{16}$ Various studies in developing countries that used relatively high doses of $\mathrm{Zn}$, ranging from 88 to $150 \mathrm{mg}$ per week, in pre-school children for up to 15 months have reported significant reduction respiratory and gastrointestinal infections with out adverse effects. $^{32,33}$

Several studies reported increased plasma and bronchoalveolar lavage fluid (BALF) levels of various cytokines such as IL-8 in patients with CF even in newly diagnosed infants with and with out documented airway infections. $^{10,34-39}$ One report showed increased IL-8 in plasma and BALF and increased in sera IL- 8 was associated with age in CF subjects as compared to serum IL-8 from normal children which decreases with age. ${ }^{35}$ Along with IL-8, increased TNF- $\alpha$ is also found in BALF samples from CF subjects and similar to IL-8, is inversely correlated to lung function FEV1. ${ }^{34}$ BALF levels of both IL-8 and TNF- $\alpha$ tend to decrease with antibiotic therapy. Compared to normal controls, other dysregulations of immune function have been reported in CF subjects such as decreased plasma IL-10 in response to antigenic stimuli, ${ }^{40,41}$ increased plasma adhesion molecules sICAM and sE-selectin, ${ }^{42}$ and decreased IL-8 production in isolated T cells. ${ }^{30}$ In other studies, results reflect data obtained from CF populations separated into groups of responders versus non-responders based on the cytokine studied. However, rarely has the $\mathrm{Zn}$ status of these patients been considered even though some subjects with $\mathrm{CF}$ are known to exhibit lower plasma Zn levels. Studies performed in non-CF adults and elderly demonstrate that plasma levels of inflammatory cytokines and oxidative stress markers are reduced following $\mathrm{Zn}$ therapy ${ }^{16-18,31}$ and provide support for $\mathrm{Zn}$ as an anti-inflammatory agent in $\mathrm{CF}$

Results of our research in humans and in cell models indicate the effect of $\mathrm{Zn}$ in reducing inflammatory cytokines is at the mRNA level and involves inhibition of NF- $\kappa \mathrm{B}$ activation. ${ }^{43} \mathrm{HL}-60$ cells, (a promyelocytic cell line) rendered $\mathrm{Zn}$ deficient and then stimulated with LPS, produce significantly greater amounts of TNF- $\alpha$, IL- $1 \beta$ and IL- 8 than those cells that were $\mathrm{Zn}$ sufficient. ${ }^{43}$ Activation of the NF- $\kappa \mathrm{B}$ pathway by $P$. aeroginosa in subjects with $\mathrm{CF}$ and in $\mathrm{CF}$ animal models can lead to an overproduction of adhesion molecules, inflammatory cytokines (IL- $1 \beta$, TNF- $\alpha$, IL- 6 , and IL-8), and oxidative stress molecules, which in turn continue to provide stimulus for further NF- $\kappa \mathrm{B}$ activation and the relentless vicious cycle. ${ }^{44,45}$

The most significant observation in this present study was the association of $\mathrm{Zn}$ supplementation with the reduction in the average days of oral antibiotic usage required to treat RTIs particularly in $\mathrm{Zn}$ inadequate subjects. It is possible that a more profound effect of $\mathrm{Zn}$ than inflammatory cytokine reduction was to modulate the airway environment. The effect of $\mathrm{Zn}$ on pulmonary function also include such events as inhibition of NADPH oxidase which generate extracellular superoxide anions ${ }^{11}$ and the restoration of chloride secretion across the $\mathrm{CF}$ airway epithelia independent of changes in the CFTR as has been demonstrated in the CF mouse model ${ }^{13}$ In the CF mouse model, direct application of ATP and Zn was shown to trigger calcium entry via the $\mathrm{P} 2 \mathrm{X}$ purinergic receptor channels leading to the activation of calcium-dependent chloride channels, circumventing the defective cyclic AMP dependent CFTR chloride channel. ${ }^{13} \mathrm{Zn}$ therapy can also modulate pulmonary sodium absorption via epithelial sodium channel $(\mathrm{ENaC})$ directly and through the regulation of redox conditions. ${ }^{46}$ The height of the airway surface liquid lining the apical side of the respiratory epithelium is tightly regulated and involves a balance between sodium absorption by $\mathrm{ENaC}$ and chloride secretion by the CFTR in normal children or by activation of the calcium-dependent chloride channel in CF with defective CFTR. Inducing "near normal" airway environmental conditions by $\mathrm{Zn}$ in $\mathrm{CF}$ would provide for suboptimal condition for infectious organisms. ${ }^{47}$

In summary, we have provided evidence that $30 \mathrm{mg}$ /day supplemental $\mathrm{Zn}$ was associated with reduction in the number of days of oral antibiotics used to treat RTI and marginal reduction in the level of plasma inflammatory cytokines in children with CF. Our study has several limitations. The number of patients with $\mathrm{CF}$ was not large enough to enhance the potential differences between the treated groups. As a result, this study can be considered as 
a pilot study providing preliminary data for power analysis for future studies designed with larger number of subjects. Slightly higher doses of $\mathrm{Zn}$ therapy may be needed to statistically change anthropometric measures, lung function, the level of plasma inflammatory cytokines, and attenuate the severity of pulmonary exacerbations in subjects with CF. Finally, the effectiveness of $\mathrm{Zn}$ therapy may be optimally determined by assessing cytokine levels in BALF or sputum samples which would more directly representative of inflammation in the compartmentalized $\mathrm{CF}$ airways. Further investigations are needed to understand the role of $\mathrm{Zn}$ in mediating pulmonary infection in CF subjects.

\section{ACKNOWLEDGMENTS}

The authors are very thankful to CF Services Pharmacy for supplying Vitamax ${ }^{\circledR}$ tablets free of charge. We are also very grateful to Cathy Van Wagnen and her invaluable help as a research nurse during the course of the study period.

\section{REFERENCES}

1. Rommens JM, Ianuzzi MC, Karem B, Drumm ML, Melmer G, Dean M, Rozmahel R, Cole JL, Kennedy D, Hidaka N, Siga M, Buchwald M, Riordan JR, Tsui LC, Collins FS. Identification of the cystic fibrosis gene: chromosome walking and jumping. Science 1989;245:1059-1065.

2. Riordan JR, Rommens JM, Karem B, Alon N, Rozmahel R, Grzelczak Z, Zielinski J, Lok S, Plavsic N, Chon JL, Drumm MC, Ianuzzi MC, Collins FS, Tsui LC. Identification of the cystic fibrosis gene: cloning and characterization of complementary DNA. Science 1989;245:1066-1073.

3. Karem B, Rommens JM, Buchannan JA, Markiewicz D, Cox T, Chakravarti A, Buchwald M, Tsui LC. Identification of the cystic fibrosis gene: genetic analysis. Science 1989;245:1073-1080.

4. Easley D, Krebs N, Jefferson M, Miller L, Erskine J, Accurso F, Hambidge KM. Effect of pancreatic enzymes on zinc absorption in cystic fibrosis. J Pediatr Gastro Nutr 1998;26:136-139.

5. Krebs NF, Wescott JE, Arnold TD, Kluger BM, Accurso FJ, Miller LV, Hambidge KM. Abnormalities in zinc homeostasis in young infants with cystic fibrosis. Pediatr Res 2000;48:256261.

6. Rosenfeld M, Gibson RL, McNamara S, Emerson J, Burns IL, Castile R, Hiall P, McCoy K, Wilson CB, Inglis A, Smith A, Martin TR, Ramsey BW. Early pulmonary infections, inflammation and clinical outcomes in infants with cystic fibrosis. Pediatr Pulmonol 2001;32:356-366.

7. Chmiel JF, Berger M, Konstan MW. The role of inflammation in the pathology of CF lung disease. Clin Rev Allergy Immunol 2002;23:5-27.

8. Gibson RL, Burns JL, Ramsey BW. Pathophysiology and management of pulmonary infections in cystic fibrosis. Am J Resp Crit Care Med 2003;168:918-951.

9. Cantin AM. Potential for antioxidant therapy of cystic fibrosis. Curr Opin Pulm Med 2004;10:531-536.

10. Chmiel JF, Konstan MW. Anti-inflammatory medications for cystic fibrosis lung disease. Treat Respir Med 2005;4:255273.

11. Zalewski PD. Zinc metabolism in the airway: basic mechanisms and drug targets. Curr Opin Pharmacol 2006;6:237-243.
12. Childers M, Eckel G, Himmel A, Caldwell J. A new model of cystic fibrosis pathology; Lack of transport of glutathione and its thiocyanate conjugates. Med Hypothesis 2007;68:101-112.

13. Zsembery A, Fortenberry JA, Liang L, Bebok Z, Tucker TA, Boyce AT, Braunstein GM, Welty E, Bell PD, Sorscher EJ, Clancy JP, Schwiebert EM. Extracellular zinc and ATP restore chloride secretion across cystic fibrosis airway epithelia by triggering calcium entry J. Biol Chem 2004;279:10720-10729.

14. Taylor CG, Bray TM. Effect of hyperoxia on oxygen free radical defense enzymes in the lung of zinc-deficient rats. J Nutr 1991; 121:460-466.

15. Sazawal S, Black RE, Jalla S, Mazumdar S, Sinha A, Bhan MK. Zinc supplementation reduces the incidence of acute lower respiratory infections in infants and preschool children: a doubleblind, controlled trial. Pediatrics 1998;102:1-5.

16. Prasad AS, Bao B, Beck FW, Kucuk O, Sarkar FH. Antioxidant effect of zinc in humans. Free Rad Biol Med 2004;37:1182-1190.

17. Prasad AS, Fitzgerald JT, Bao B, Beck FWJ, Chandraeskar PH. Duration of symptoms and plasma cytokine levels in patients with the common cold treated with zinc acetate. Ann Int Med 2000; $133: 245-252$.

18. Prasad AS, Beck FWJ, Bao B, Fitzgerald JT, Snell DC, Steinberg JD, Cardozo LJ. Zinc supplementation decreases incidence of infection in the elderly: effect of zinc on the generation of cytokines and oxidative stress. Am J Clin Nutr 2007;85:837-844.

19. Akanli L, Lowenthal DB, Gjonaj S, Dozor AJ. Plasma and red blood cell zinc in cystic fibrosis. Pediatr Pulmonol 2003;25:2-7.

20. Safai-Kutti S, Selin E, Larsson S, Jagenburg R, Denfors I, Sten G, Kjellmer I. Zinc therapy in children with cystic fibrosis. Beitr Infusionsther 1991;27:104-114.

21. Mocchegiani E, Provinciali M, Di Stefano G, Nobilini A, Caramia G, Santarelli L, Tibaldi A, Fabris N. Role of the low zinc bioavailability on cellular immune effectiveness in cystic fibrosis. Clin Immunol Immunopathol 1995;75:214-224.

22. Beck FWJ, Li Y, Bao B, Prasad AS, Sarkar FH. Evidence for reprogramming global gene expression during zinc deficiency in the HUT-78 cell line. Nutrition 2006;22:1045-1056.

23. In: Burtis CA, Ashwood ER, editors. Tietz textbook of clinical chemistry. 3rd edition. Philadelphia, PA: W.B. Saunders Co.; 1999.

24. Krebs NF, Sontag M, Accurso FJ, Hambidge JM. Low plasma zinc concentrations in young infants with cystic fibrosis. J Pediatr 1998;133:761-764.

25. Maqbool A, Schall JI, Zemel BS, Garcia-Espana JF, Stallings VA. Plasma zinc and growth status in preadolescent children with cystic fibrosis. J Pediatr Gastroenterol Nutr 2006;43:95-101.

26. Navarro J, Dequilbet N. Depressed plasma vitamin A and retinolbinding protein in cystic fibrosis correlates with zinc deficiency. Am J Clin Nutr 1981;34:1439-1440.

27. Jacob RA, Sandstead HH, Solomons NW, Rieger C, Rothberg R. Zinc status and vitamin A transport in cystic fibrosis. Am J Clin Nutr 1978;31:638-644.

28. Neve J, Van Geffel R, Hanocq M, Molle L. Plasma erythrocyte zinc, copper and selenium in cystic fibrosis. Acta Paediatr Scand 1993;72:437-440.

29. Prasad AS, Meftah S, Abdallah J, Kaplan J, Brewer GJ, Dardenne M. Serum thymulin inhuman zinc deficiency. J Clin Invest 1986; 82:1202-1210.

30. Hubeau C, Le Naour R, Abely M, Hinnrasky J, Guenounou M, Giallard D, Puchelle E. Dysregulation of IL-2 and IL-8 production in circulating $\mathrm{T}$ lymphocytes from young cystic fibrosis patients. Clin Exp Immunol 2004;135:528-534.

31. Prasad AS, Beck FWJ, Kaplan J, Chandrasekar PH, Ortega J, Fitzgerald JT, Swerdlow P. Effect of zinc supplementation on the incidence of infections and hospital admissions in sickle cell disease (SCD). Am J Hematol 1999;61:194-202. 
32. Bates CJ, Evans PH, Dardenne M, et al. A trial of zinac supplementation in young rural Gambian Children. Br J Nutr 1993;69:243-255.

33. Aggarwal R, Sentz J, Miller MA. Role of zinc administration in prevention of childhood diarrhea and respiratory illnesses: a meta-analysis. Pediatrics 2007;119:1120-1130.

34. Colombo C, Costantini D, Rocchi A, Cariani L, Garlaschi ML, Tirelli S, Calori G, Copreni E, Conese M. Cytokine levels in sputum of cystic fibrosis patients before and after antibiotic therapy. Pediatr Pulmonol 2005;40:15-21.

35. Dean TP, Dai Y, Shute JK, Church MK, Warner JO. Interleukin-8 concentrations are elevated in bronchoalveolar lavage, sputum and sera of children with cystic fibrosis. Pediatr Res 1993;34: $159-161$.

36. Noah TL, Black HR, Cheng PW, Wood RE, Leigh MW. Nasal and bronchoalveolar lavage fluid cytokines in early cystic fibrosis. J Infect Dis 1997;175:638-647.

37. Muhlebach MS, Stewart PW, Leigh MW, Noah TL. Quantitation of inflammatory response to bacteria in young cystic fibrosis and control patients. Am J Respir Crit Care Med 1999;160:186-191.

38. Khan TZ, Wagener JS, Bost T, Martinez J, Accurso FJ, Riches DWH. Early pulmonary inflammation in infants with cystic fibrosis. Am J Respir Crit Care Med 1995;151:1075-1082.

39. Armstrong DS, Grimwood K, Carlin JB, Carzino R, Gutierrez JP, Hull J, Olinsky A, Phelan EM, Robertson CF, Phelan PD. Lower airway inflammation in infants and young children with cystic fibrosis. Am J Respir Crit Care Med 1997;156:1197-1204.
40. Brazova J, Sediva A, Pospisilova D, Vavravo V, Pohunek P, Macek M, Bartunkova J, Lauschmann H. Differential cytokine profile in children with cystic fibrosis. Clin Immunol 2005;115: $210-215$

41. Shmarina GV, Pukhalsky AL, Kokarovtseva SN, Pukhalskya DA, Shabalova LA, Kapranov NI, Kashirskaja NJ. Tumor necrosis factor- $\alpha /$ interleukin- 10 balance in normal and cystic fibrosis children. Mediators Inflamm 2001;10:191197.

42. De Rose V, Ilova A, Messore B, Grosso B, Mollar C, Popzzi E. Circulating adhesion molecules in cystic fibrosis. Am J Respir Crit Care Med 1998;157:1234-1239.

43. Bao B, Prasad AS, Beck FWJ, Godmere M. Zinc modulates mRNA levels of cytokines. Am J Physiol Endocrinol Metab 2003; 285:E1095-E1102.

44. Christman JW, Sadikot RT, Blackwell TS. The role of nuclear factor- $\kappa$ B in pulmonary diseases. Chest 2000;117:14821487.

45. Saadane A, Soltys J, Berger M. Role of IL-10 deficiency in excessive nuclear factor- $\mathrm{kB}$ activation and lung inflammation in cystic fibrosis transmembrane conductance regulator knockout mice. J Allergy Clin Immunol 2005;115: 405-411.

46. Kellerberger S, Gautschi I, Pfister Y, Schild L. Intracellular thiolmediated modulation of epithelial sodium channel activity. J Biol Chem 2005;280:7739-7747.

47. Thelin WR, Boucher RC. The epithelium as a target for therapy in cystic fibrosis. Curr Opin Pharmacol 2007;7:1-6. 